UDC 811.11

УДК 811.11

\author{
Anastasia D. Melnik \\ Don State Technical University \\ Rostov-on-Don, Russia \\ Мельник Анастасия Дмитриевна \\ Донской государственный технический университет \\ г. Ростов-на-Дону, Россия \\ anastasha82@yandex.ru
}

\title{
FIXED PHRASE PATTERNS WITH A COMPULSORY UNCHANGEABLE COMPONENT - AN INTERROGATIVE WORD \\ IN GERMAN: THE ANTHROPOCENTRIC APPROACH \\ ФРАЗЕОСИНТАКСИЧЕСКИЕ СХЕМЫ С ОПОРНЫМ КОМПОНЕНТОМ - ВОПРОСИТЕЛЬНЫМ СЛОВОМ В НЕМЕЦКОМ ЯЗЫКЕ: АНТРОПОЦЕНТРИЧЕСКИЙ ПОДХОД
}

\begin{abstract}
The purpose of the article is to describe the main properties of the fixed phrase patterns with a compulsory unchangeable component - an interrogative word in German. The following methods are used: description, observation, syntactic modeling, phraseological, etymological and contextual analysis, transformation method elements and discourse analysis. The material for analysis was obtained from 2 German corpora (COSMAS and DWDS) and included fiction of the XIX-XXI centuries as well as media texts. The research procedure consisted of several stages: collecting the material, analyzing it, and summing up the results. The study was carried out in accordance with anthropocentric approach with the primary focus on usage patterns. The corpus for the study included 2000 contexts of the fixed phrase patterns found in the material. Etymology and functioning patterns of those schemes were examined. The results clearly indicate that firstly, the fixed phrase patterns correspond to the status of the units of the phraseological subsystem of the language. Secondly, they serve as an effective means of communication, realizing various communicative intentions of the author in the text. Consequently, they are anthropocentric by nature expressing an emotional and evaluative attitude to what is indicated, pursuing the goal of influencing the addressee, encouraging him/her to such evaluations and experiences. Finally, the obtained results contribute to deeper understanding of the fact that the meaning of any phraseological unit is encoded information that needs to be decoded. It is impossible to fully understand the functional side of the fixed phrase patterns phenomenon (as any language phenomenon) without addressing the language speaker - the creator and user of the language.
\end{abstract}

\footnotetext{
Аннотация

Цель статьи - описать основные свойства фразеосхем с обязательным неизменяемым компонентом - вопросительным словом в немецком языке. В работе использованы метод описания, метод наблюдения, метод синтаксического моделирования, фразеологический, этимологический и контекстуальный анализ, элементы трансформационного метода и дискурс-анализ. Материал для анализа был получен из 2-х немецких корпусов (COSMAS и DWDS), включающих художественные тексты XIX-XXI вв., а также медиатексты. Процедура исследования состояла из нескольких этапов: сбор материала, его анализ и подведение итогов. Анализ проводился с позиций антропоцентрического подхода. В ходе исследования было обнаружено 2000 контекстов употребления фразеосхем, которые сформировали корпус исследования. Анализу подверглись этимология и функционирование указанных фразеосхем. Выявлено, что, вопервых, фразеосхемы с обязательным неизменяемым компонентом - вопросительным словом точно соответствуют статусу единиц фразеологической подсистемы языка. Во-вторых, они служат эффективным средством общения, реализуя различные коммуникативные намерения автора в тексте. Следовательно, они антропоцентричны по своей природе и выражают эмоционально-оценочное отношение к тому, что
} 
обозначается, преследуя цель воздействия на адресата, побуждая его к подобным оценкам и переживаниям. Наконец, полученные результаты вносят вклад в понимание того, что смысл любой фразеологической единицы - это зашифрованная информация, требующая расшифровки. Невозможно до конца понять функциональную сторону фразеосинтаксических схем (как и любого другого феномена языка), не обратившись к носителю языка - его создателю и пользователю.

Keywords: fixed phrase scheme, anthropocentric approach, German, compulsory unchangeable component, syntactic phraseology, syntactic phraseological unit, idiomaticity.

Ключевые слова: фразеосхема, антропоцентрический подход, немецкий язык, обязательный неизменяемый компонент, синтаксическая фразеология, синтаксическая фразеологическая единица, идиоматичность.

doi: 10.22250/2410-7190_2020_6_3_77_84

\section{Introduction}

Phraseology as a language subsystem includes different levels: morphological, lexical and syntactic phraseology. Syntactic phraseology is a new direction in the syntax and phraseology of the language that has formed a separate field within linguistics.

«Syntactic phraseology aims to study linguistic units that combine the properties of two linguistic levels - phraseology and syntax. These are high-frequency linguistic units in many spoken languages of the world. Their uniqueness lies in the fact that they have a structural template but an infinite variation of lexical content and a great variety of meanings that they express. Syntactic and lexical levels of phraseology are characterized by different types of phraseological units» [Melnik, Melikyan, 2018].

This research is based on well-known verifiable data and dwells upon the fundamental theoretical principles formulated in the works of a number of linguists who studied the problems of phraseology and syntactic phraseology including D. N. Shmelev [Shmelev, 1977], N. Yu. Shvedova [Shvedova, 1958], N. A. Yanko-Trinitskaya [Yanko-Trinitskaya, 1969] etc.

The study of phraseological units at the syntactic level was started by D. N. Shmelev and N. Yu. Shvedova who applied the semantic-structural approach to their research. N. Yu. Shvedova investigated phraseological units as a phenomenon typical for spoken language [Shvedova, 1958] while D. N. Shmelev focused on coherent syntax. He offered the term 'fixed phrase patterns' for the structures, which are based on a fixed pattern for the construction and composed of words with limited grammatical variation. In his works, D. N. Shmelev described the basic properties of the fixed phrase patterns and the features that distinguish them from the lexical idioms [Shmelev, 1977].

Syntactic phraseology has received considerable attention in Russian linguistics, while in Germanic philology syntactic phraseology was studied as a constituent element within other linguistic fields: stylistics, grammar, rhetoric, culture of speech, lexicology, etc. Literature analysis [Melnik, 2017 b, p. 118] shows that fixed phrase patterns in Germanic philology have not received their proper description being the focus of study only in few works (see e.g. [Fleischer, 1997; Burger, 2010; [Schmidt, 2010]). This fact determines the necessity for further study, and the current paper is an attempt to contribute into the field.

Previous studies of fixed phrase schemes have shown that currently in modern linguistics the scientists describe a fixed phrase pattern with different supporting compulsory components, distinguishing the following groups of fixed phrase patterns: a supporting compulsory component, expressed by a pronoun [Melikyan, 2007], a not fully notional word, a pronominal word, an interjection, a preposition [Akbaeva, 2016], an adverb (interrogative and non-interrogative) [Belozerova, 2007], a fully notional [Dallakyan, 2010], an interrogative word [Melnik, 2019], a conjunction [Vakulenko, 2014], etc. 
Syntactic phraseological units (hereinafter referred to as SPU) are diverse and numerous. In modern linguistics it is customary to distinguish four classes of SPU: 'communikems' (word-sentences), phrase-syntactic schemes (fixed phrase patterns), stable models and steady turns.

«The existence of phraseological and syntactic meaning in SPU is determined by the fact that it is inherent in the sentence as a unit of syntax, expressed in the construction as a whole, is stable and invariant, is not directly taken from the structure of the model, is not motivated by the grammatical connection existing between the components of the model» [Melikyan, 2017, p. 66].

All classes of SPU are actively used by speakers. Fixed phrase patterns are the brightest representative of the SPU. There are different definitions of fixed phrase patterns in modern linguistics. In this research, I adhere to the following definition of fixed phrase patterns: «Fixed phrase pattern is the communicative predicative unit of syntax, representing a defined and reproducible proprietary syntax scheme, characterized by the presence of dictumus and moduses propositions (meanings), expressing the judgment or impulse, with grammatical and lexical partial inseparability, reduced permeability and being spread and performing the expressive function in the speech. Structural model of fixed phrase pattern suggests the presence of two binding components, one of them is supporting both in the lexical and grammatical aspects, the second is variable, i.e. freely lexically varied and grammatically stable» [Melikyan, 2007, p. 69].

Following V. Yu. Melikyan [Melikyan, 2007; 2014; 2016; 2017], Yu. M. Belozerova [Belozerova, 2007], O. V. Akbaeva [Akbaeva, 2016], O. G. Dallakyan [Dallakyan, 2010], D. A. Vakulenko [Vakulenko, 2014], this study applies anthropocentric approach to SPU. It should be noted that the idea of the anthropocentricity of language is generally accepted, since in almost all linguistic studies a person acts as a natural point of reference. Syntactic phraseology is not an exception. Being a subsystem of the phraseological system of a language, it is heterogeneous and multidimensional, which implies the possibility of considering phraseological schemes characterizing human speech in various aspects. With the anthropocentric approach, the human factor becomes the main factor determining the development, functioning and character of SPU. Thus, in determining the functionalpragmatic aspect of the SPU, the person and speech are taken as a point of reference. Phraseological units in general and syntactic phraseological units (in particular, fixed phrase patterns) are anthropocentric by nature.

The importance of the anthropocentric principle in the study of syntactic phraseology is determined by the fact that the language is inextricably linked with the thinking, consciousness and personality. This determines the interest in the human factor in the study of linguistic phenomena, in particular SPU. In the study of syntactic phraseology, the principle of anthropocentrism ensures that the human factor is viewed as the major factor determining the relevant properties and speech patterns of phrase-syntactic schemes.

SPU act as one of the most striking means of emotionally expressive phrases of communicative meaning. That was a strong motive for the current study. The focus of this study is the fixed phrase pattern with a compulsory unchangeable component - an interrogative word in German.

\section{This study}

\subsection{Methods and material}

This study is the continuation of the previous research [Melnik, 2017a, b; 2019] with more focus on anthropocentric approach to the patterns analyzed. The methodology for the study of syntactic phraseology also includes the principles of consistency and determinism. 
A number of methods were used in this work. Observation and description were used to identify fixed phrase patterns with an interrogative word as the compulsory unchangeable component as the specific language phenomena as well as to reveal the patterns of their functioning in speech. Contextual analysis was applied to study functional features in greater detail. The etymological analysis defined SPU origin. Phraseological analysis helped identify the phraseological meaning of the fixed phrase pattern as a distinct linguistic category. Component analysis enabled to describe SPU structure. Syntactic modeling allowed to build a specific model of the investigated SPU with a multi-component structure. Using transformational analysis, a more complex syntactic structure of each fixed phrase pattern was derived, based on a simpler initial structure due to its transformations. Descriptive statistics was applied to determine the frequency of the patterns and meanings in particular genres.

The chosen approach, principles and methods give a comprehensive view of the phenomenon of syntactic phraseology under study.

The material for analysis was obtained from 2 German corpora (COSMAS and DWDS), including fiction of the XIX-XXI centuries as well as media texts. The research process consisted of several stages: collecting the material, analyzing it and summing up the results. 2000 examples of ten fixed phrase patterns in contexts were analyzed (about 100-200 per each fixed phrase pattern).

For processing of the material, continuous sampling, automatic and semi-automatic keyword search were applied. At the initial research stage the searched keyword was the compulsory component of each fixed phrase scheme (an interrogative German word), then all occurrences of a particular scheme were considered. Wrong samples were filtered out manually. The samples were identified and classified in accordance with the meanings they expressed in a particular context reflecting emotional, perceptual, mental, pragmatic and other moduses of human language and speech.

\subsection{Results}

The results of the analysis clearly indicate that SPU originate from the interrogative sentences, in particular, special questions.

Among five functional speech styles that were involved in the search, in three of them the studied fixed phrase patterns were found: journalistic style, conversational style and fiction. Their highest frequency is mainly shown in the last two styles $(70 \%$ of the total number).

Table 1 demonstrates the 10 found patterns, their frequency rates, particular meanings and genres / styles where they frequently appeared.

$\mathrm{T}$ a $\mathrm{b} 1 \mathrm{e}$ 1. Fixed phrase patterns with an interrogative word as the compulsory unchangeable component

\begin{tabular}{|c|c|l|c|}
\hline Pattern & $\begin{array}{c}\text { Number of } \\
\text { occurrences / } \\
\text { Percentage of the } \\
\text { pattern to the total } \\
\text { number of patterns }\end{array}$ & Meanings & $\begin{array}{c}\text { Frequent } \\
\text { genre / style }\end{array}$ \\
\hline $\begin{array}{c}\text { «Was für }+ \\
\text { Sub }\end{array}$ & $400 / 20 \%$ & $\begin{array}{l}\text { 1) negative evaluation } \\
\text { 2) positive evaluation } \\
\text { 3) a high degree of manifestation of the subject of } \\
\text { speech in combination with a variety of emotions }\end{array}$ & $\begin{array}{c}\text { journalistic, } \\
\text { conversational, } \\
\text { fiction }\end{array}$ \\
\hline $\begin{array}{c}\text { «Was für }+ \\
\text { Sub } 1-4 ! »^{2}\end{array}$ & $260 / 13 \%$ & $\begin{array}{l}\text { 1) surprise combined with a negative evaluation of } \\
\text { the subject of speech, condemnation, indignation, } \\
\text { censure }\end{array}$ & $\begin{array}{c}\text { conversational, } \\
\text { fiction }\end{array}$ \\
\hline
\end{tabular}


Continuation of Table 1

\begin{tabular}{|c|c|c|c|}
\hline Pattern & $\begin{array}{l}\text { Number of } \\
\text { occurrences / } \\
\text { Percentage of the } \\
\text { pattern to the total } \\
\text { number of patterns }\end{array}$ & Meanings & $\begin{array}{c}\text { Frequent } \\
\text { genre / style }\end{array}$ \\
\hline $\begin{array}{l}\ll \text { Was für }+ \\
\mathrm{Sub}_{1-4} !{ }^{2}\end{array}$ & $260 / 13 \%$ & $\begin{array}{l}\text { 2) inducement to stop any actions in combination } \\
\text { with condemnation, indignation } \\
\text { 3) denial of the fact and its evaluation in } \\
\text { combination with disdain, disapproval, indignation }\end{array}$ & $\begin{array}{l}\text { conversational, } \\
\text { fiction }\end{array}$ \\
\hline $\begin{array}{l}\text { «Was + Verb } \\
+ \text { Pron }_{1} !(?) »\end{array}$ & $300 / 15 \%$ & $\begin{array}{l}\text { 1) denial combined with a high degree of } \\
\text { confidence, irony, negative attitude to the subject of } \\
\text { speech and the interlocutor, indignation } \\
\text { 2) statement in combination with a high degree of } \\
\text { manifestation of the subject of speech and a variety } \\
\text { of emotions: "everything", "much" } \\
\text { 3) evaluating a fact as noteworthy, combined with } \\
\text { perplexity, doubt, and a variety of emotions }\end{array}$ & $\begin{array}{c}\text { conversational, } \\
\text { fiction }\end{array}$ \\
\hline $\begin{array}{l}\text { «Was }+ \text { Pers. } \\
\quad \text { Pron } 1+ \\
<\text { nicht }>+ \\
\text { Verb!(?)» }\end{array}$ & $240 / 12 \%$ & $\begin{array}{l}\text { 1) surprise combined with a positive evaluation of } \\
\text { the subject of speech, approval, admiration, joy } \\
\text { 2) surprise combined with a negative evaluation of the } \\
\text { subject of speech, resentment, censure, irony, ridicule }\end{array}$ & $\begin{array}{l}\text { conversational, } \\
\text { fiction }\end{array}$ \\
\hline $\begin{array}{l}\ll \text { Wie }+ \text { Adj } \\
{[\text { Adv }]+} \\
<\text { sein }>+ \\
\text { Pron }_{1} ! »\end{array}$ & $140 / 7 \%$ & $\begin{array}{l}\text { 1) positive evaluation combined with surprise, } \\
\text { positive attitude to the subject of speech and the } \\
\text { interlocutor, approval, admiration } \\
\text { 2) negative evaluation combined with surprise, } \\
\text { negative attitude to the subject of speech and the } \\
\text { interlocutor, irony, disapproval, disappointment, } \\
\text { annoyance } \\
\text { 3) a high degree of manifestation of the subject of speech } \\
\text { in combination with surprise and various emotions }\end{array}$ & $\begin{array}{c}\text { conversational, } \\
\text { fiction }\end{array}$ \\
\hline $\begin{array}{c}\text { «Wie + Verb + } \\
\text { Pron }_{1} !(?) »\end{array}$ & $200 / 10 \%$ & $\begin{array}{l}\text { 1) statement combined with a high degree of } \\
\text { confidence and a variety of emotions } \\
\text { 2) denial combined with a high degree of } \\
\text { confidence and a variety of emotions } \\
\text { 3) surprise combined with a negative evaluation of } \\
\text { the subject of speech, perplexity, disapproval, } \\
\text { indignation, disappointment }\end{array}$ & $\begin{array}{c}\text { conversational, } \\
\text { fiction }\end{array}$ \\
\hline $\begin{array}{l}\text { «Wo + Verb + } \\
\text { Pron }_{1} !(?) »\end{array}$ & $120 / 6 \%$ & $\begin{array}{l}\text { 1) denial of the subject of speech, disagreement } \\
\text { combined with a high degree of confidence } \\
\text { 2) statement of fact, agreement combined with a } \\
\text { high degree of confidence as well as surprise, } \\
\text { outrage, and other various emotional shades }\end{array}$ & $\begin{array}{l}\text { conversational, } \\
\text { fiction }\end{array}$ \\
\hline $\begin{array}{l}\text { «Warum }+ \\
\text { Verb }+ \text { Pron }_{1} ! \\
(?) »\end{array}$ & $100 / 5 \%$ & $\begin{array}{l}\text { 1) affirmation } \\
\text { 2) negation } \\
\text { 3) inducement to (not)perform an action } \\
\text { 4) negative evaluation }\end{array}$ & $\begin{array}{c}\text { journalistic, } \\
\text { fiction }\end{array}$ \\
\hline $\begin{array}{c}\text { «Wer }+ \text { Verb } \\
(?) ! »\end{array}$ & $140 / 7 \%$ & $\begin{array}{l}\text { 1) denial combined with a high degree of } \\
\text { confidence, surprise, irony, and disapproval } \\
\text { 2) statement combined with a high degree of } \\
\text { confidence and a variety of emotions }\end{array}$ & $\begin{array}{c}\text { journalistic, } \\
\text { fiction }\end{array}$ \\
\hline $\begin{array}{l}\text { «Wann + Verb } \\
+\operatorname{Pron}_{1}(?) ! »\end{array}$ & $100 / 5 \%$ & $\begin{array}{l}\text { 1) denial of the fact, which is formally asked, } \\
\text { combined with surprise, often with a negative } \\
\text { attitude to the subject of speech and the interlocutor } \\
\text { 2) negative evaluation of the subject of speech } \\
\text { combined with surprise, regret, irritation, indignation }\end{array}$ & $\begin{array}{l}\text { journalistic, } \\
\text { fiction }\end{array}$ \\
\hline
\end{tabular}


As can be seen from Table 1, the patterns are characterized by different frequency and express from 2 to 4 meanings in different contexts. All the 10 patterns were found in fiction, 7 appeared in conversational style, and 4 were present in journalistic genre. The first and the most frequent pattern (20\%) occurred in all the three genres. Obviously, the emotional component with its particular meanings is of great importance for understanding the idea of each of the 10 patterns.

The degree of phraseologization of each fixed phrase pattern differs. For example, the pattern with wie has a relatively high degree of phraseologization, which is manifested to a large extent in the deactivation of the semantic content of the lexeme wie as a part of the phrase scheme as well as in the absence of the practice of putting a question mark at the end of a sentence while maintaining the syntactic structure of the interrogative sentence.

The pattern with wie or was, like all other fixed phrase patterns of this type (with a compulsory unchangeable component - an interrogative word), is formed from simple interrogative sentences (special questions). For example: «fixed phrase scheme «Was für + Sub1-4!» is a derivative, the basis of which is the interrogative syntactic construction, which is a simple interrogative sentence of non-phraseological type (special question)...: Sie sind lang in Paris gewesen, mein Herr. Wo spricht man da am besten? Was für Einen haben Sie da am meisten nach Ihren Geschmack gefunden? (G. E. Lessing. Der Fuchs und der Storch)» [10, p. 68]. In the given context the sentence Was für Einen haben Sie da am meisten nach Ihren Geschmack gefunden? is an interrogative sentence, with no frasiologization, but in the fixed phrase scheme with a compulsory unchangeable component - an interrogative word (in the given example it is was für) is deactualized; deactualizaion of the meaning of a compulsory unchangeable component in the structure of the fixed phrase scheme manifests itself in partial or total loss of significance «questioning». This leads to the transformation of the functional status of the syntactic structure from interrogative to narrative or exclamation, to the weakening of syntactic relations between the components of the syntactic structure, fixing the order of their sequence, the loss of relevance of the syntactic relations between them. The compulsory unchangeable component performs the function of a lexico-grammatical element, i.e. is grammaticalization, and the meaning of fixed pattern becomes phrasesyntactic. For example: «Oh nein, Stop sto... - Was für ein Planet ist das da vorn! - Eine unwichtige bedeutungslose Welt, mein Lord. (Star Trek: Of Gods And Men. German subtitels, 2007)». Here the sentence Was für ein Planet ist das da vorn! functions as a fixed phrase pattern.

The investigated various fixed phrase patterns with a compulsory unchangeable component - an interrogative word («Was für + Sub1-4!», «Was für + Sub1-4!», «Wie + Adj [Adv] $+<$ sein $>+$ Pron1!», «Wie + Verb + Pron1!(?)» and others) confirm their phraseological status by the presence of all the features characteristic for all the units of phraseological subsystem of the language: idiomatic, reproducible, structural-semantic stability and integrity, expressiveness and colloquial stylistic marking. All these properties are vividly illustrated by the phraseologization of the enantiosemic fixed phrase scheme «Wie + Verb + Pron1!(?)».

The result of this phraseologization is the loss of its semantic segmentation, partial or complete desemantization of structural elements, the formal stability of the syntactic model, the limitations of the morphological paradigm of this construction and a certain order of components.

The analysis of the examples illustrating this fixed phrase pattern functioning in speech showed that the productivity of the meanings expressed by this phrase pattern is different. Most often, in speech, the meaning of a high degree of manifestation of the subject of speech is combined with a variety of emotions. For example: «Als regulierendes Prinzip nennt er, wie könnte es anders sein, einen «natürlichen Preis» der Güter, in denen sich das Kapital inkarniert» (R.Kurz. Schwarzbuch Kapitalismus). In this example, the affirmative phrase Wie könnte es anders sein expresses a negative meaning "It could not be otherwise" in 
combination with a high degree of confidence, etc. The phraseosyntactic meaning due to the specifics of the syntactic structure does not depend on its specific lexical content and belongs to the syntactic scheme of the sentence as a whole.

Idiomaticity is one of the most important features. It is associated with the asymmetry of the expression plane and the content plane of a fixed phrase pattern, deducibility of the phrasesyntactic meaning of a positive or negative evaluation as well as a high degree of intensity of the manifestation of the subject of speech from the meanings of the individual structural components of a fixed phrase scheme. For example: «Sie schreiben, dass ich demnächst zehn Prozent mehr fürs Gas bezahlen soll. Was für eine gute Nachricht! Zwar hätte ich nie gedacht, dass ich mich einmal über eine Preiserhöhung freuen würde» (Die Zeit, 03.06.2009). In this example, the meaning of a negative assessment («bad news») of the fixed phrase scheme Was für eine gute Nachricht!, the value of a high degree of intensity of the subject of speech («very»), and the content of the modus proposition («perturbation, irony, etc.») are not explicitly represented in the lexical content of the fixed phrase pattern. For example, the dictum meaning of the following fixed phrase pattern is «the girl sings very well»: Wie dieses Mädchen gut sing! / Aus dem Gespräch/. In addition to the meaning of «the girl sings very well», this fixed phrase pattern also explicates such emotional shades of meaning as «surprise, admiration, etc.», which do not have a formal representation in the syntactic structure.

The content of the modus proposition of the fixed phrase pattern, which is associated with the expression of the speaker's attitude to the subject of the speech, is idiomatic.

\section{Conclusion}

The study of syntactic phraseology units makes it possible to resolve a significant number of issues concerning the general theory of phraseology. A multi-aspect study of phraseology as a language subsystem helps to formulate more precisely the standard patterns of their usage in speech as well as to improve the effectiveness of the communication process.

This study has looked at the fixed phrase schemes with a compulsory unchangeable component - an interrogative word in the German language that, as all other SPU, are anthropocentric by nature. The performed analysis of the national corpus materials discovered 10 patterns in the German language of the fixed phrase pattern with a compulsory unchangeable component - an interrogative word.

As can be seen from the analysis of the fixed phrase patterns with a compulsory unchangeable component - an interrogative word from the point of view of the anthropocentric approach, they reflect in their semantics and structure the principles of an anthropocentric approach to knowledge in the language consciousness of a person.

All the fixed phrase patterns have different meanings in the language system, reflecting the versatility of the person's nature (communicant's nature), who uses them in speech.

These fixed phrase patterns are all polysemic. The dominant part has negative meanings, which are generally characteristic of the formation of phraseological units in all languages of the world. The emotional expression of the studied units is related in meaning to human feelings and, as a rule, expresses a positive or a negative attitude to the subject of speech. The variety of expressive properties of fixed phrase patterns and their specificity express a subjectiveemotional attitude manifested by the fact that the described state or quality acts through the prism of the individual-emotional perception of the communicant. The investigated patterns express an emotional and evaluative attitude to what is designated, pursuing the goal of influencing the addressee, prompting him/her to similar assessments and experiences.

This study has contributed to deeper understanding of the facts that, first, the meaning of any phraseological unit is information that requires decoding, and second, it is impossible to fully comprehend the functional side of the language without referring to its creator and user - the language speaker. 


\section{References}

Akbaeva, O. V. (2016). Frazeosintaksicheskiye skhemy s opornym komponentomnepolnoznamenatel'nym slovom: strukturnyy $i$ funktsional'nyy podkhody (na materiale russkogo yazyka) [Fixed phrase schemes with a compulsory component-not fully notional word: structural and functional approaches (in Russian language)]: PhD in Philological sci. diss. Maykop : Adygea State University.

Belozerova, Yu. M. (2007). Strukturno-semanticheskiy, etimologicheskiy, paradigmaticheskiy i rechevoy aspekty opisaniya frazeosintaksicheskikh skhem s opornym komponentom-narechiem (na materiale russkogo yazyka) [Structural-semantic, etymological, paradygmatical and speech aspects of fixed phrase schemes with a compulsory component-adverb description (in the Russian language)]. PhD in Philological sci. diss. Rostov n/D : Southern Federal University.

Burger, H., Schmidt, E. (2010). Phraseologie. Eine Einführung am Beispiel des Deutschen. 4th ed. Berlin.

Dallakyan, O. G. (2010). Frazeosintaksicheskie skhemy s opornymi komponentami dalsya, nashyol, nashyol kto, nashyolsya, nado zhe, nuzhno, okhota: yazyk i rech' [Fixed phrase schemes with a compulsory component was given, found, found someone, found, must, need, hunt: language and speech]. PhD in Philological sci. diss. Rostov n/D : Southern Federal University.

Fleischer, W. (1997). Phraseologie der deutschen Gegenwartssprache. Tübingen.

Melikyan, V. Yu. (2007). Frazeosintaksicheskie skhemy s mestoimennym komponentom v sisteme russkogo yazyka [Fixed phrase schemes with a pronominal component in the system of the Russian language]. Russkiy yazyk v shkole [Russian language in school], 6, 69-74.

Melikyan, V. Yu. (2014). Frazeosintaksicheskie skhemy s opornym komponentom polnoznamenatel'nym slovom: strukturno-semanticheskiy i funktsional'nyy aspekty [Phraseosyntactic schemes with a compulsory component-a full-name word: structural-semantic and functional aspects]. Russkiy yazyk v shkole [Russian Language at School], 8, 66-72.

Melikyan, V. Yu. (2017). Sovremennyy russkiy yazyk: sintaksicheskaya frazeologiya [Modern Russian language: syntactic phraseology]: A coursebook. Rostov-on-Don.

Melikyan, V. Yu. (2016). Slovar' ekspressivnykh ustoychivykh fraz russkogo yazyka. Frazeoskhemy $i$ ustoychivye modeli [Dictionary of expressive stable phrases of the Russian language. Fixed phrase schemes and stable models]. Rostov-on-Don.

Melnik, A., Melikyan, V. (2018). The fixed phrase scheme «Wie + AF (?)!» in the system of German: Structural, semantic, etymological and phraseological aspects. 5th International Multidisciplinary Scientific Conference on Social Sciences and Arts SGEM 2018, www.sgemsocial.org, SGEM2018 Conference Proceedings, ISBN 978-619-7408-58-4 / ISSN 2367-5659, 26 August - 1 September, 2018, (Vol. 5, Issue 3.6, pp. 593-600).

Melnik, A. D. (2017 a). Frazeoskhema «Was für + Sub1-4!» v sisteme nemetskogo yazyka [The Phraseoscheme "Was Für + Sub1-4!" in the System of German Language]. Izvestiya Yuzhnogo federal'nogo universiteta. Filologicheskie nauki [Proceedings of Southern Federal University. Philology], 3, 66-74.

Melnik, A. D. (2019). Frazeologizirovannye sintaksicheskie konstruktsii v nemetskom yazyke [Phraseological syntactic constructions in German]. PhD in Philological sci. diss. Rostov-on-Don : Southern Federal University.

Melnik, A. D. (2017 b). Frazeoskhema s opornym komponentom wie v nemetskom yazyke: strukturnosemanticheskiy, etimologicheskiy i frazeologicheskiy aspekty [The phrase scheme with the basic component WIE in the German language: Structural-semantic, etymological and phraseological aspects]. Aktual'nyye problemy filologii i pedagogicheskoy lingvistiki [Current Issues in Philology and Pedagogical Linguistics], 3 (27), 117-124.

Shmelev, D. N. (1977). Sovremennyy russkiy yazyk. Leksika [Modern Russian language. Vocabulary] : A course book. Moscow.

Shvedova, N. Yu. (1958). O nekotorykh tipakh frazeologizirovannykh konstruktsiy v stroe russkoy razgovornoy rechi [On some types of phraseological constructions in the structure of Russian colloquial speech]. Voprosy yazykoznaniya [Topics in the Study of Language], 2, 93-100.

Vakulenko, D. A. (2014). Frazeosintaksicheskie skhemy s opornym komponentomsoyuzom: yazyk $i$ rech' (na materiale russkogo yazyka) [Fixed phrase schemes with a compulsory component conjunction: Language and speech (Based on Russian)]. PhD in Philological csi. diss. Maykop: Adyghe State University.

Yanko-Trinitskaya, N. A. (1969). Frazeologichnost' yazykovykh edinits raznykh urovney yazyka [Phraseology of language units of different language levels]. Izvestiya AN SSSR [Bulletin of the Academy of Sciences of the USSR], 5 (5), 429-436. 